Article

\title{
Residual Maintenance Using Sodium Hypochlorite, Sodium Dichloroisocyanurate, and Chlorine Dioxide in Laboratory Waters of Varying Turbidity
}

\author{
Karin Gallandat ${ }^{1,2, *}$, David Stack ${ }^{1}$, Gabrielle String ${ }^{1}\left[\right.$ and Daniele Lantagne ${ }^{1}$ \\ 1 Department of Civil and Environmental Engineering, Tufts University, Medford, MA 02155, USA; \\ dlstack7@gmail.com (D.S.); gabrielle.string@tufts.edu (G.S.); daniele.lantagne@tufts.edu (D.L.) \\ 2 Department of Disease Control, London School of Hygiene and Tropical Medicine, Keppel St, London, \\ WC1E 7HT, UK \\ * Correspondence: karin.gallandat@lshtm.ac.uk
}

Received: 11 May 2019; Accepted: 19 June 2019; Published: 25 June 2019

\begin{abstract}
Sodium hypochlorite $(\mathrm{NaOCl})$ and sodium dichloroisocyanurate $(\mathrm{NaDCC})$ are commonly used for household water treatment (HWT); chlorine dioxide $\left(\mathrm{ClO}_{2}\right)$ is a potential new HWT option. We compared the residual maintenance of $\mathrm{NaOCl}, \mathrm{NaDCC}$, and $\mathrm{ClO}_{2}$ over 24 hours using recommended dosages ( 2 and $4 \mathrm{mg} / \mathrm{L}$ ) in waters of varying turbidity (0-300 NTU, from kaolin clay or creek-bottom sediments) and total organic carbon (TOC) concentrations $(0-100 \mathrm{mg} / \mathrm{L})$, for a total of 324 reactors. $\mathrm{NaOCl}$ and $\mathrm{NaDCC}$ had similar free chlorine decay rates, and $\mathrm{ClO}_{2}$ decayed more rapidly across all of the tested conditions. Little variability was observed across clay-based turbidity levels and TOC concentrations. With a dosage of $2 \mathrm{mg} / \mathrm{L}$, a residual $\geq 0.2 \mathrm{mg} / \mathrm{L}$ was maintained at $30 \mathrm{NTU}$ for $\mathrm{NaOCl}$ and $100 \mathrm{NTU}$ for NaDCC; for $\mathrm{ClO}_{2}, 4 \mathrm{mg} / \mathrm{L}$ were required to maintain $\geq 0.2 \mathrm{mg} / \mathrm{L}$ under all conditions except at zero turbidity. Comparisons with data from the literature suggest that the three compounds would inactivate E. coli, rotavirus, and Giardia cysts within 1 hour under all conditions, except $300 \mathrm{NTU}$ for $\mathrm{NaOCl}$ and $\mathrm{NaDCC}$. All three disinfectants are similarly efficacious for this usage; however, differences are seen in decay rates that may influence disinfectant selection depending on water storage time.
\end{abstract}

Keywords: chlorination; chlorine; chlorine dioxide; decay; disinfection; household water treatment; sodium dichloroisocyanurate; sodium hypochlorite; residual

\section{Introduction}

Worldwide, approximately 2.1 billion people lack access to a safely managed drinking water service, including 582 million people who use unimproved or surface water sources [1]. Household water treatment (HWT) can be a cost-effective means of improving drinking water quality [2] and reducing diarrheal disease in households where access to safe water is limited [3]. HWT is therefore recommended as part of a comprehensive strategy to prevent infections and to improve the health of vulnerable populations without access to safe drinking water in low-resource and emergency settings $[4,5]$.

Chlorination is a common HWT method, and chlorination programs generally include three elements: Water treatment with a chlorine product, such as liquid sodium hypochlorite $(\mathrm{NaOCl})$ or tablets of sodium dichloroisocyanurate $(\mathrm{NaDCC})$ at the household level; the storage of treated water in a safe container; and a behavior change communication to improve water handling practices and hygiene [6]. In a meta-analysis of 21 health impact studies of household chlorination with sodium hypochlorite, the overall reduction in diarrheal disease averaged $29 \%$ in users and $41 \%$ in confirmed 
users [7]. Currently, bottles of liquid chlorine and chlorine tablets are widely marketed and distributed in development and emergency contexts [8-10].

A limitation of chlorination is the need to determine the appropriate dosage for each water source, which depends on the "chlorine demand" [11]. This chlorine demand is the amount of chlorine consumed by reactions with various organic and inorganic substances present in the water matrix, and is empirically determined for each source. In each water source, the chlorine dosage must be sufficient to account for this chlorine demand, before disinfection can occur. Chlorine demand is exerted by a set of compounds, including, but not limited to: Natural organic materials (e.g., phenols, amines, acids, aldehydes, ketones, pyrrole groups, and inorganics and metals (ammonia, arsenic, iron, manganese), and halides (including sulfide, bromide, cyanide, iodide)) [12-14]. These reactions can be instantaneous (e.g., with metals) or first- or second-order decay reactions over time. Additionally, biofilm growth, the material of pipes (or storage containers), exposure to ultraviolet (UV) from sunlight, $\mathrm{pH}$, temperature and contact time all impact chlorine residual decay over time [12,15].

The concentration of natural organic material in water is typically expressed as total organic carbon (TOC), which is the sum of dissolved and particulate organic carbon. Natural organic material is dominated by the presence of humic substances, such as fulvic and humic acids. Several equations are empirically derived to describe chlorine demand kinetics as a function of total organic carbon (TOC) $[12,14]$. However it is cautioned that these relationships are specific to water matrix conditions, and are not representative of all waters.

Turbidity is often used as a rough indicator for chlorine demand and/or TOC, despite the limitations of this metric, because it is simple to measure [16]. In a study of 158 drinking water sources from 22 low-income countries, measured drinking water turbidity ranged from 0-551 nephelometric turbidity units (NTU) [16]. It was determined that an $\sim 2 \mathrm{mg} / \mathrm{L}$ chlorine dosage for water from improved sources of $<5$ or $<10$ NTU turbidity met free chlorine residual (FCR) criteria of $\geq 0.2 \mathrm{mg} / \mathrm{L} 91-94 \%$ and $82-87 \%$ of the time after 8 and 24 hours of storage, respectively. In unimproved water source samples, a $\sim 4 \mathrm{mg} / \mathrm{L}$ dosage met $\geq 0.2 \mathrm{mg} / \mathrm{L} 83 \%$ and $65 \%$ of the time after 8 and 24 hours, respectively. Based on these results, the Centers for Disease Control and Prevention (CDC, Atlanta, Georgia) and the World Health Organization (WHO) recommend to adapt chlorine dosage for HWT depending on turbidity (as an indicator for chlorine demand): $2 \mathrm{mg} / \mathrm{L}$ for waters with $<10 \mathrm{NTU}$ turbidity, and $4 \mathrm{mg} / \mathrm{L}$ at higher turbidity levels [16-18]. Direct chlorination is not recommended for waters with $>100$ NTU turbidity [16]. These dosage guidelines were developed specifically for HWT to ensure: 1) The inactivation of bacterial and viral pathogens present in the water; and, 2) the maintenance of an adequate FCR ( $\geq 0.2-0.5 \mathrm{mg} / \mathrm{L})$ to prevent recontamination over 24 hours of household storage.

The dosage guidelines are applicable to both $\mathrm{NaOCl}$ and $\mathrm{NaDCC}$. However, there is interest in using other disinfectants, particularly chlorine dioxide $\left(\mathrm{ClO}_{2}\right)$, which has been commercialized for point-of-use water treatment by several companies in recent years [19-22]. $\mathrm{NaOCl}, \mathrm{NaDCC}$, and $\mathrm{ClO}_{2}$ have varying chemical characteristics (Table 1).

Table 1. Characteristics of the three tested disinfectants.

\begin{tabular}{cccccc}
\hline Compound & $\begin{array}{c}\text { Chemical } \\
\text { Formula }\end{array}$ & $\begin{array}{c}\text { Mol. Weight } \\
(\mathbf{g} / \mathbf{m o l})\end{array}$ & pH in Solution & $\begin{array}{c}\text { Biocidal } \\
\text { Compound }\end{array}$ & $\begin{array}{c}\text { Typical } \\
\text { Packaging }\end{array}$ \\
\hline Sodium hypochlorite & $\mathrm{NaOCl}$ & 74.44 & $11-12$ & $\mathrm{HOCl}$ & $\mathrm{Liquid}$ \\
Sodium dichloroisocyanurate & $\mathrm{NaC}_{3} \mathrm{~N}_{3} \mathrm{O}_{3} \mathrm{Cl}_{2}$ & 219.95 & $6-7$ & $\mathrm{HOCl}$ & $\begin{array}{c}\text { Powder, tablets } \\
\text { Chlorine dioxide }\end{array}$ \\
$\mathrm{ClO}_{2}$ & 67.45 & $\mathrm{n} / \mathrm{a}$ & $\mathrm{ClO} 2(\mathrm{~g})$ & Liquid, tablets \\
\hline
\end{tabular}

$\mathrm{NaOCl}$ is a hypochlorite salt soluble in water and has been used for drinking water disinfection since the early 1900s [12]. In water, $\mathrm{NaOCl}$ releases hypochlorous acid $(\mathrm{HOCl})$, which exerts a biocidal activity [12].

$\mathrm{NaOCl}$ solutions (commonly termed "bleach") can be produced locally or regionally by passing gaseous chlorine into a stream of water, by diluting powdered chlorine, or by the electrolysis of salt and water [23]. Sodium hydroxide is added to ensure a 12-18 month shelf-life by raising the $\mathrm{pH}$ 
(towards a higher alkalinity) [24]. The use of $\mathrm{NaOCl}$ in the presence of organic compounds can lead to disinfectant by-product formation, including trihalomethane (THM) formation, long-term ingestion of which can increase cancer risk [25]. If CDC- and WHO-recommended dosages are used, the THM concentrations remain below WHO guideline values, even at high turbidity levels [26]. In low-resource settings, $\mathrm{NaOCl}$ solutions are usually packaged in bottles with instructions to add one full bottle cap of the solution to clear water (or two caps to turbid water) in a standard sized storage container, then to agitate and afterwards wait 30 minutes before drinking [6].

$\mathrm{NaDCC}$ is industrially produced as a white crystalline powder, which can be tabletized, with a shelf-life of 3-5 years [8,27]. While both $\mathrm{NaOCl}$ and $\mathrm{NaDCC}$ release $\mathrm{HOCl}$ as biocidal compound for disinfection, the release mechanism is slightly different for $\mathrm{NaDCC}$, as free chlorine release from NaDCC is mediated by cyanurate molecules [28]. NaDCC use also leads to THM formation, although if recommended dosages are used, these THM concentrations remain below WHO guideline values [29]. In low-resource settings, NaDCC is typically packaged in strips or bottles, and its users are instructed to add one tablet to clear water (or two to turbid water), to agitate, and then wait 30 minutes before drinking [6].

$\mathrm{ClO}_{2}$ is a gas at room temperature, and exists almost entirely as monomeric free radicals, with a relatively constant efficacy over a wider $\mathrm{pH}$ range (6-10) than chlorine $[12,30] \cdot \mathrm{ClO}_{2}$ use has increased in recent decades due to lower THM formation potential, higher efficacy in treating viruses, and stronger oxidation power than sodium hypochlorite [30]. Recently, $\mathrm{ClO}_{2}$ has been promoted for HWT use, and packaged as a liquid [19] or in the form of tablets [20]. To our knowledge, the appropriate dosage and residual maintenance for $\mathrm{ClO}_{2}$ use for HWT has not been evaluated.

Thus, a knowledge gap exists about the relative residual maintenance over 24 hours-to ensure safety during household water storage - of the three disinfectants. The majority of research to date on FCR maintenance is with $\mathrm{NaOCl}$, with some conducted on $\mathrm{NaDCC}[16,31]$. There is a common perception that $\mathrm{NaDCC}$ maintains higher $\mathrm{FCR}$ over time than $\mathrm{NaOCl}$ (due to the mediation by cyanurate molecules), particularly in turbid waters. However, there is only limited evidence to support this at drinking water concentrations, and studies highlight that more research is needed at higher turbidity levels $[16,31]$.

The goal of the research presented herein is to compare residual maintenance over 24 hours using recommended dosages for $\mathrm{NaOCl}, \mathrm{NaDCC}$, and $\mathrm{ClO}_{2}$ in laboratory-controlled waters with varying turbidity and added TOC levels to inform recommendations for HWT.

\section{Materials and Methods}

From June to December 2016, we prepared 10-L reactors with two types of added turbidity at five different turbidity levels and three added TOC concentrations, then treated these with one of three disinfectants at the $\mathrm{CDC} / \mathrm{WHO}$ recommended dosage (Figure 1), and measured the disinfectant residual at 1, 2, 4, 8, and 24 hours after disinfectant addition. As there was no difference in the turbidity type at 0 NTU, 162 conditions were tested in duplicate, for a total of 324 reactors.

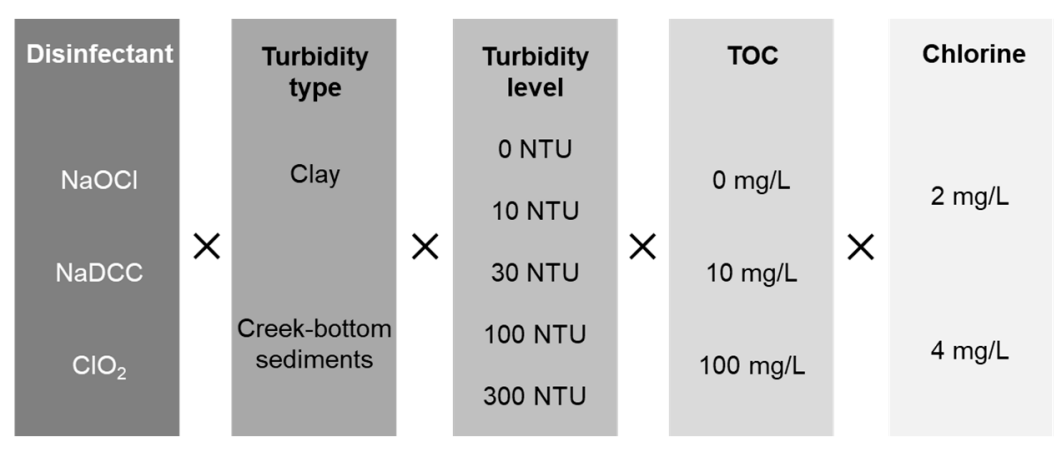

Figure 1. Testing matrix. 


\subsection{Turbidity}

To represent various turbidity types seen in surface water used for drinking in low-resource settings, reactors were spiked with laboratory-grade white kaolin clay (Lion China Clay USP, Charles B. Chrystal Co., Larchmont, NY, US) or creek bottom sediments collected from the Mystic River (Medford, MA, US). The 0, 10, 30, 100, and 300 NTU targets were set to be consistent with previous research and with chlorine dose breakpoints $[16,32,33]$. Pre-testing was conducted to determine the amount of clay/sediments required to obtain turbidity targets in reactors using a calibrated Hach 2100 portable turbidimeter (Loveland, CO, US).

Twenty-four hours before each testing day, creek bottom sediments were collected from a consistent location on the Mystic River. Using a plastic scoop, one inch of the soil layer where the river met the bank was removed to eliminate any rocks. The softer soil below was then scooped into a gallon-sized Ziploc ${ }^{\mathrm{TM}}$ bag (Racine, WI, US) and transported to the laboratory. On each testing day, clay or sediments were added, and the turbidity was confirmed to be within $10 \%$ of the target. If any results were outside this range, the reactor was recreated.

\subsection{TOC}

To obtain the desired added TOC concentration, an appropriate amount of 10,000 mg/L TOC stock solution comprised of 1,2 bensenedicarboxylic acid, monopotassium salt $(2.11 \% \mathrm{wt})$ and phosphoric acid $(0.27 \% \mathrm{wt}$ ) was pipetted into each reactor (Hach, Loveland, CO, USA) [34]. The 0, 10, and $100 \mathrm{mg} / \mathrm{L}$ concentrations were selected to encompass the range of naturally occurring waters [35]. After addition, each opaque reactor was covered with cardboard to protect the TOC molecules from light.

\subsection{Disinfectants and Dose}

The CDC/WHO recommended dosages of 2 and $4 \mathrm{mg} / \mathrm{L}$ for clear and turbid water, respectively, were tested for each disinfectant under all turbidity and TOC conditions. To determine the volume of the $\mathrm{NaOCl}$ solution ("bleach") to add to reactors, the Hach digital titration method 8209 (Loveland, $\mathrm{CO}, \mathrm{USA}$ ) was used to measure the total chlorine concentration in a laboratory-grade $\mathrm{NaOCl}$ solution (Val Tech, Zelienople, PA, US) and the dilution factors were calculated. For NaDCC, the number of non-expired Aquatabs ${ }^{\mathrm{TM}}$-brand tablets (Medentech, Ireland) to add to the reactors was calculated, and the dosages were confirmed by measuring the total chlorine residual five minutes after addition to chlorine demand-free water, using a calibrated LaMotte 1200 colorimeter with DPD-1 and DPD-3 (N,N-diethylparaphenylene diamine) tablets (Chestertown, MD, USA). Pre-testing was conducted with chlorine demand-free water to determine the appropriate volume of liquid $\mathrm{ClO}_{2}$ product (Xinix $\mathrm{AB}$, Rosersberg, Sweden) to add to the reactors in order to achieve target dosages. The determined dosages were added and confirmed using the colorimeter with DPD-1.

\subsection{Reactor Testing}

Immediately before disinfectant addition, the temperature and $\mathrm{pH}$ in each reactor were measured using a thermometer and a calibrated Hanna multi-meter (Bedfordshire, UK). After disinfectant addition, FCR or $\mathrm{ClO}_{2}$ were measured at $0,1,2,4,8$, and 24 hours using the LaMotte colorimeter following methods approved by the United States Environmental Protection Agency (EPA) for disinfectant residual testing, namely the Standard Method 4500-Cl-G for FCR, and 4500-ClO2-D for $\mathrm{ClO}_{2}$ [36,37]. Please note that for $\mathrm{ClO}_{2}$ measurements, we did not use glycine as recommended in Standard Method 4500-ClO2-D, because this is intended to neutralize free chlorine, which was not present in the MilliQ water used in our experiments. Standard Methods include zeroing the colorimeter with the water sample as a blank before adding the DPD-1 to minimize turbidity/TOC interference in the test. 
Measurements were reported in $\mathrm{mg} / \mathrm{L}$ at two significant digits, as determined to be the accuracy and precision of the meter in previous research [38]. Temperature, $\mathrm{pH}$, and turbidity were measured 24 hours after addition (as described above). All meters were calibrated daily.

\subsection{Data Analysis}

All data were entered and graphs prepared in Microsoft Excel (Redmond, WA, US). Statistical analyses were run in STATA 14.1 (StataCorp LP, College Station, TX, US). FCR and $\mathrm{ClO}_{2}$ decays were evaluated by fitting the mean of the duplicate measurements obtained at $0,1,2,4,8$, and 24 hours for each disinfectant, dosage, turbidity type, turbidity level, and added TOC concentration to a first-order model.

Three different metrics were then used to assess the results: 1) Whether decay rates differed between tested compounds; 2) whether measured residual concentrations exceeded the WHO/CDC-recommended minimum for FCR of $0.2 \mathrm{mg} / \mathrm{L}$ after 24 hours; and, 3) whether the dose and contact time (CT-factor) were sufficient to inactivate representative bacteria, virus, and protozoa. Each of these metrics is further described below.

First-order decay constants $k$ were determined by fitting the following first-order decay equation for each dosage, turbidity type, and turbidity level:

$$
\ln \left(\frac{C_{t}}{C_{0}}\right)=-k t
$$

where $C_{t}$ is the FCR concentration at time $t$ (in hours), and $C_{0}$ the initial FCR concentration.

Disinfectant decay rates were compared using an analysis of covariance (ANCOVA) with both time and the natural log of residual concentrations as covariates. Tukey's post-hoc tests were used to determine which disinfectants differed, if any.

For each dosage, type, and turbidity, the measured residual after 24 hours was compared to the CDC/WHO guideline target of a minimum of $0.2 \mathrm{mg} / \mathrm{L}$. A particular point of investigation was assessing "policy-relevant" differences, where one disinfectant met the minimum concentration and another did not.

Lastly, to compare disinfectant efficacy in disinfecting water, we calculated the CT-factors. The CT-factor is the multiple of the disinfectant concentration and the exposure time, and quantifies the contact time and the dose needed to inactivate the organisms [39]. CT-factors were calculated for the 1-hour and 24-hour time points for all of the tested combinations of turbidity and dosage by multiplying the measured FCR or chlorine dioxide residual concentration at each point by 60 minutes (for the 1-hour time point) or 1,440 minutes (for the 24-hour time point), respectively. Please note this is a conservative calculation, as the residual concentration at the end time point was used for the whole time.

These results were compared to known CT-factors for selected bacteria (Escherichia coli), virus (human rotavirus), and protozoa (Giardia lamblia). We chose E. coli because it is the standard bacteria to use for water quality analysis [17], human rotavirus because it is the etiologic agent most responsible for childhood diarrhea in developing countries [40], and Giardia cysts because they are common, and chlorination is not effective against any of the Cryptosporidium spp. [39].

\section{Results}

In total, 324 reactors were tested (as shown in Figure 1 in Methods). All reactors met the desired criteria for turbidity on first creation, except for three $(0.9 \%)$, which were prepared again.

\subsection{Free Chlorine and Chlorine Dioxide Residual Decay}

Free chlorine decays over time in all of the samples (Figure 2). There is little variation between samples with different added TOC concentrations and different turbidities created with clay (Figure 3 , 
Figure S1). As such, samples with creek bottom sediments at the added TOC concentration $10 \mathrm{mg} / \mathrm{L}$ are presented in Figure 2 (please note all data and results are available from the authors). As can be seen, $\mathrm{NaOCl}$ and $\mathrm{NaDCC}$ decay curves appear similar, with increasing decay at increasing turbidities, and chlorine dioxide decays more rapidly across all turbidities.
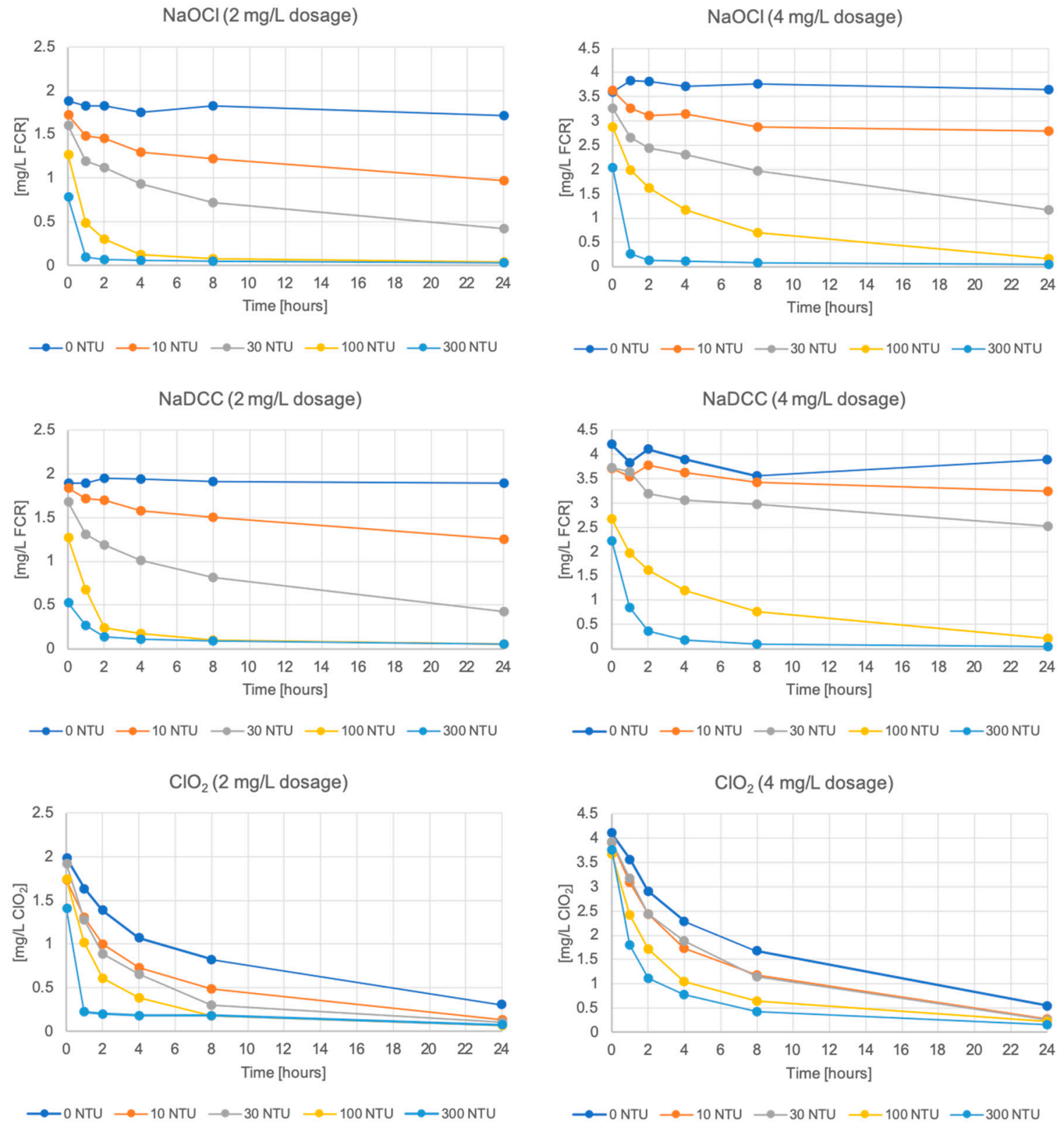

Figure 2. Disinfectant residual concentration over time at constant added TOC (10 mg/L) and varying turbidity from creek-bottom sediments. 

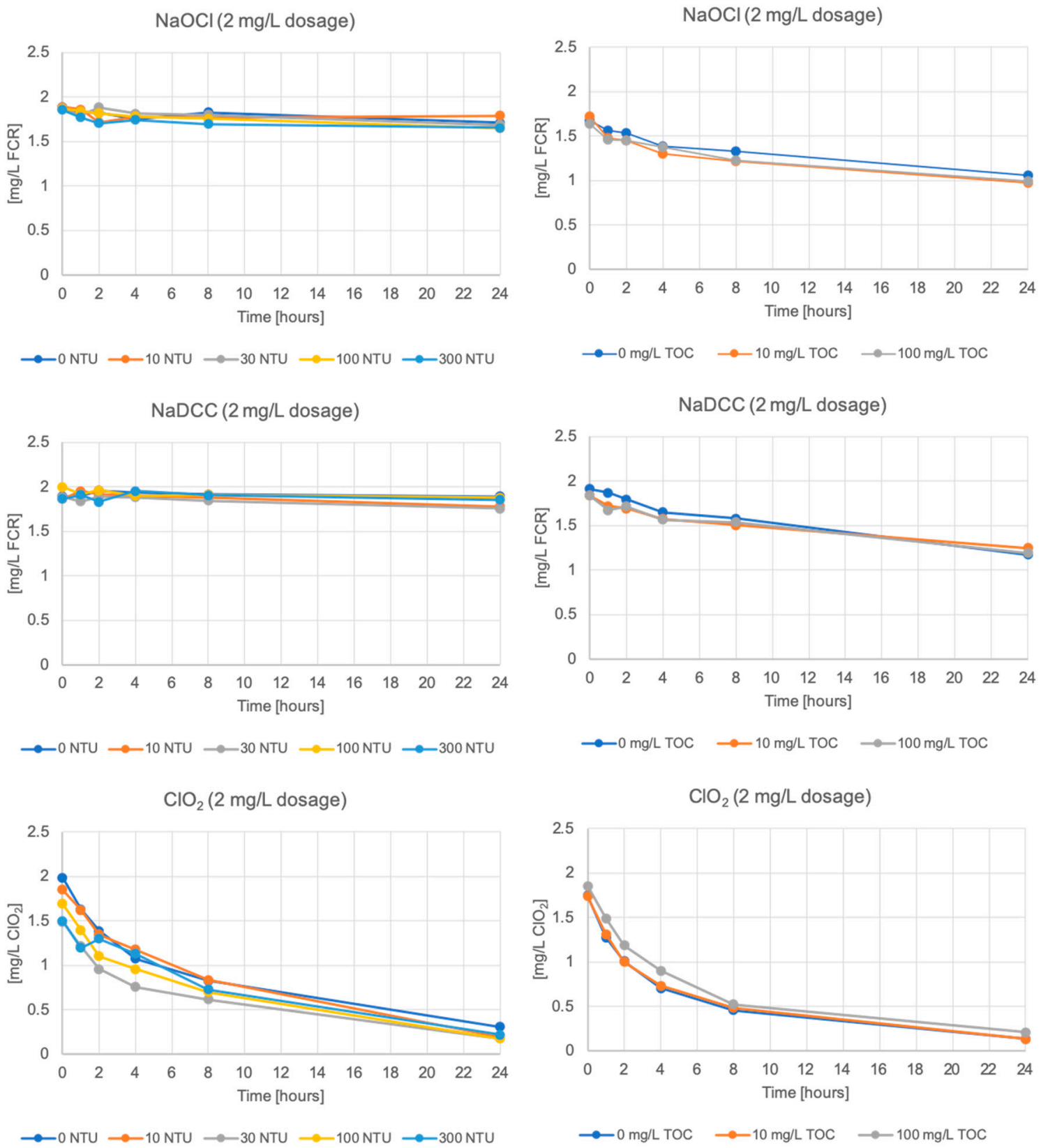

Figure 3. Disinfectant residual concentration over time at varying turbidity from clay (left) and varying added TOC (right) for the $2 \mathrm{mg} / \mathrm{L}$ dosage.

First-order decay constants $k$ are calculated from duplicates across the three added TOC levels $(n=6)$ for each dosage and turbidity condition (Table 2). Significant differences between disinfectants $(\mathrm{p} \leq 0.0004)$ are detected for all dosage and turbidity conditions by ANCOVA. Post-hoc test results indicate that $\mathrm{ClO}_{2}$ decay rates are significantly different from those of $\mathrm{NaOCl}$ and $\mathrm{NaDCC}$ under all but two cases (for both dosages at a turbidity of $100 \mathrm{NTU}$ from creek-bottom sediments). $\mathrm{NaOCl}$ and $\mathrm{NaDCC}$ decay rates are statistically significantly different under 5 out of 18 cases, at both dosages with 30 and $100 \mathrm{NTU}$ sediment and at $4 \mathrm{mg} / \mathrm{L}$ dosage with $300 \mathrm{NTU}$ sediment. All p-values from the post-hoc test are reported in Table S1. 
Table 2. First-order decay constants $k\left(\mathrm{~h}^{-1}\right)$ for sodium hypochlorite (NaOCl), sodium dichloroisocyanurate $(\mathrm{NaDCC})$, and chlorine dioxide $\left(\mathrm{ClO}_{2}\right)$ (based on duplicates grouped across three added total organic carbon (TOC) concentrations levels, $\mathrm{n}=6$ for each condition).

\begin{tabular}{|c|c|c|c|c|c|c|c|}
\hline \multirow{2}{*}{$\begin{array}{c}\text { Turbidity } \\
\text { Type }\end{array}$} & \multirow{2}{*}{$\begin{array}{l}\text { Turbidity } \\
\text { Level [41] }\end{array}$} & \multicolumn{2}{|c|}{$\mathrm{NaOCl} k\left(\mathrm{~h}^{-1}\right)$} & \multicolumn{2}{|c|}{ NaDCC $k\left(h^{-1}\right)$} & \multicolumn{2}{|c|}{$\mathrm{ClO}_{2} k\left(\mathrm{~h}^{-1}\right)$} \\
\hline & & $2 \mathrm{mg} / \mathrm{L}$ & $4 \mathrm{mg} / \mathrm{L}$ & $2 \mathrm{mg} / \mathrm{L}$ & $4 \mathrm{mg} / \mathrm{L}$ & $2 \mathrm{mg} / \mathrm{L}$ & $4 \mathrm{mg} / \mathrm{L}$ \\
\hline N/A & 0 & -0.0042 & -0.0012 & -0.0034 & -0.0039 & -0.0752 & -0.0824 \\
\hline \multirow{4}{*}{ Clay } & 10 & -0.0029 & -0.0013 & -0.0020 & -0.0021 & -0.0942 & -0.0985 \\
\hline & 30 & -0.0041 & -0.0021 & -0.0035 & -0.0019 & -0.0866 & -0.1009 \\
\hline & 100 & -0.0038 & -0.0021 & -0.0028 & -0.0033 & -0.0966 & -0.0999 \\
\hline & 300 & -0.0034 & -0.0013 & -0.0028 & -0.0027 & -0.0878 & -0.0942 \\
\hline \multirow{4}{*}{ Sediment } & 10 & -0.0188 & -0.0110 & -0.0168 & -0.0069 & -0.0952 & -0.1005 \\
\hline & 30 & $-0.0545^{*}$ & $-0.0515^{*}$ & $-0.0405^{*}$ & $-0.0258^{*}$ & -0.1075 & -0.1008 \\
\hline & 100 & $-0.1392^{*}$ & $-0.1289^{*}$ & $-0.1327^{*}$ & $-0.0819^{*}$ & $-0.1004^{\dagger}$ & $-0.1041^{\dagger}$ \\
\hline & 300 & -0.1392 & $-0.0986^{*}$ & -0.1327 & $-0.1267^{*}$ & -0.1004 & -0.0943 \\
\hline
\end{tabular}

${ }^{\dagger} \mathrm{ClO}_{2}$ decay rates are not significantly different from those of $\mathrm{NaOCl}$ and $\mathrm{NaDCC}$ (p-value 0.193-0.841). ${ }^{*} \mathrm{NaDCC}$ and $\mathrm{NaOCl}$ decay rates are significantly different $(\mathrm{p}<0.001-0.012)$.

\subsection{Meeting Minimim Standards}

For $\mathrm{NaOCl}$ and $\mathrm{NaDCC}$, the mean FCR concentrations after 24 hours are $\geq 0.2 \mathrm{mg} / \mathrm{L}$ in all reactors without added turbidity and with clay-based turbidity (Table 3). Residuals are $<0.2 \mathrm{mg} / \mathrm{L}$ in all reactors with sediments at $300 \mathrm{NTU}$, and for three of the four conditions at $100 \mathrm{NTU}$ (at both dosages for $\mathrm{NaOCl}$, at the low dosage only for $\mathrm{NaDCC}$ ).

Table 3. Mean (standard deviation) disinfectant concentration after 24 hours ( $n=6$, duplicates at three added TOC levels for each turbidity and dosage tested).

\begin{tabular}{|c|c|c|c|c|c|c|c|}
\hline \multirow{2}{*}{$\begin{array}{c}\text { Turbidity } \\
\text { Type }\end{array}$} & \multirow{2}{*}{$\begin{array}{l}\text { Turbidity } \\
\text { Level [41] }\end{array}$} & \multicolumn{2}{|c|}{$\mathrm{NaOCl}\left(\mathrm{mg} / \mathrm{L} \mathrm{Cl}_{2}\right)$} & \multicolumn{2}{|c|}{$\mathrm{NaDCC}\left(\mathrm{mg} / \mathrm{L} \mathrm{Cl}_{2}\right)$} & \multicolumn{2}{|c|}{$\left.\mathrm{ClO}_{2}(\mathrm{mg} / \mathrm{L} \mathrm{ClO})_{2}\right)$} \\
\hline & & $2 \mathrm{mg} / \mathrm{L}$ & $4 \mathrm{mg} / \mathrm{L}$ & $2 \mathrm{mg} / \mathrm{L}$ & $4 \mathrm{mg} / \mathrm{L}$ & $2 \mathrm{mg} / \mathrm{L}$ & $4 \mathrm{mg} / \mathrm{L}$ \\
\hline N/A & 0 & $1.7(0.09)$ & $3.6(0.13)$ & $1.8(0.11)$ & $3.7(0.18)$ & $0.29(0.02)$ & $0.50(0.05)$ \\
\hline \multirow{4}{*}{ Clay } & 10 & $1.7(0.09)$ & $3.6(0.09)$ & $1.9(0.11)$ & $4.0(0.14)$ & $0.17(0.07)$ & $0.31(0.13)$ \\
\hline & 30 & $1.6(0.07)$ & $3.3(0.21)$ & $1.8(0.11)$ & $3.9(0.10)$ & $0.19(0.05)$ & $0.31(0.15)$ \\
\hline & 100 & $1.6(0.08)$ & $3.5(0.16)$ & $1.8(0.11)$ & $3.8(0.11)$ & $0.17(0.10)$ & $0.32(0.17)$ \\
\hline & 300 & $1.6(0.11)$ & $3.5(0.17)$ & $1.8(0.08)$ & $3.7(0.17)$ & $0.20(0.10)$ & $0.33(0.16)$ \\
\hline \multirow{4}{*}{ Sediment } & 10 & $1.0(0.06)$ & $2.6(0.19)$ & $1.2(0.06)$ & $3.1(0.16)$ & $0.16(0.04)$ & $0.32(0.09)$ \\
\hline & 30 & $0.39(0.17)$ & $1.2(0.06)$ & $0.64(0.17)$ & $2.3(0.19)$ & $0.12(0.01)$ & $0.29(0.07)$ \\
\hline & 100 & $0.03(0.01)$ & $0.12(0.05)$ & $0.04(0.01)$ & $0.39(0.14)$ & $0.10(0.03)$ & $0.21(0.03)$ \\
\hline & 300 & $0.03(0.01)$ & $0.06(0.01)$ & $0.05(0.01)$ & $0.07(0.02)$ & $0.12(0.04)$ & $0.19(0.03)$ \\
\hline
\end{tabular}

Shaded cells indicate concentrations under the WHO/CDC threshold of $0.2 \mathrm{mg} / \mathrm{L}$ after 24 hours.

For $\mathrm{ClO}_{2}, 7$ of 9 cases at $2 \mathrm{mg} / \mathrm{L}$ dosage have $<0.2 \mathrm{mg} / \mathrm{L}$, the two remaining cases (no turbidity and $300 \mathrm{NTU}$ clay) have $<0.3 \mathrm{mg} / \mathrm{L}$. At $4 \mathrm{mg} / \mathrm{L}$ dosage, 8 of 9 cases are $\geq 0.2 \mathrm{mg} / \mathrm{L}$, with the exception of the 300 NTU sediment. Upon observation, $\mathrm{ClO}_{2}$ is more consistent across each turbidity type and level than $\mathrm{NaOCl}$ and $\mathrm{NaDCC}$.

\subsection{CT-factor Analysis}

CT-factors are found in the literature for free chlorine and $\mathrm{ClO}_{2}$ for the inactivation of E. coli, human rotavirus, and Giardia cysts (Table 4). CT-factors for the selected organisms cannot be retrieved from the three identified studies evaluating the microbial efficacy of NaDCC for water treatment [42-44]. While $\mathrm{NaDCC}$ and $\mathrm{NaOCl}$ have different chemistries and $\mathrm{HOCl}$ release mechanisms, it is postulated 
that available data on the efficacy of free chlorine for water disinfection is relevant to NaDCC, as both $\mathrm{NaOCl}$ and $\mathrm{NaDCC}$ release $\mathrm{HOCl}$; however this is unconfirmed [27].

Table 4. CT-factors (concentration $\times$ time) from the literature for free chlorine and $\mathrm{ClO}_{2}$ against selected test organisms.

\begin{tabular}{cccccc}
\hline Test Organism & Disinfectant & CT Factor $(\mathbf{m g}$ min/L) & Inactivation & Temp. $\left({ }^{\circ} \mathbf{C}\right)$ & Source \\
\hline Escherichia coli & $\mathrm{HOCl}(\mathrm{NaOCl})$ & 0.04 & $2-\log$ & 5 & {$[45]$} \\
& $\mathrm{ClO}_{2}$ & $0.18-0.38$ & $2-\log$ & $15-25$ & {$[45]$} \\
Rotavirus & $\mathrm{HOCl}$ (oxidized HCl) & $1.25-3.57$ & $3-\log$ & 20 & {$[46]$} \\
\multirow{4}{*}{ Giardia lamblia } & $\mathrm{ClO}_{2}$ & $0.13-0.32$ & $3-\log$ & 20 & {$[46]$} \\
& $\mathrm{HOCl}($ unclear) & $<9-12$ & $2-\log$ & 25 & {$[47]$} \\
& $\mathrm{ClO}_{2}$ & 10 & $2-\log$ & 20 & {$[48]$} \\
\hline
\end{tabular}

*Required for a 2-star rating according to the World Health Organization household water treatment (WHO HWT) evaluation scheme [49].

For $\mathrm{NaOCl}, \mathrm{CT}$-factors at 1 hour range from $6.0-109.3$ and $25.3-224.9 \mathrm{mg}-\mathrm{min} / \mathrm{L}$, at 2 and $4 \mathrm{mg} / \mathrm{L}$, respectively (Table S2). For NaDCC, CT-factors at 1 hour range from 9.3-118.5 and 61.8-244.6 mg-min/L, at 2 and $4 \mathrm{mg} / \mathrm{L}$, respectively. For $\mathrm{ClO}_{2}, \mathrm{CT}$-factors at 1 hour range from 41.5-62.4 and 100.2-127.0 $\mathrm{mg}$-min/L, at 2 and $4 \mathrm{mg} / \mathrm{L}$, respectively. Across all three compounds, the lowest CT-factors are at the $300 \mathrm{NTU}$ sediment and $2 \mathrm{mg} / \mathrm{L}$ dosage, the highest values are in the $4 \mathrm{mg} / \mathrm{L}$ dosage with clay (NaDCC, $\mathrm{NaOCl})$ or no turbidity $\left(\mathrm{ClO}_{2}\right)$.

CT-factors for the 1-hour time point for the three compounds are higher than the values reported to inactivate E. coli and the human rotavirus under all tested conditions (Table 4, Table S1). However, Giardia cysts have the highest CT-factor of the three selected organisms. Assuming a $9 \mathrm{mg}-\mathrm{min} / \mathrm{L}$ CT-factor necessary to inactivate Giardia, the only test condition that do not meet a 2-log inactivation is a $2 \mathrm{mg} / \mathrm{L}$ dosage of $\mathrm{NaOCl}$ in $300 \mathrm{NTU}$ sediments. Assuming a $12 \mathrm{mg}$-min/L CT-factor necessary to inactivate Giardia, the only test conditions that do not meet a 2-log inactivation are $2 \mathrm{mg} / \mathrm{L}$ dosages of $\mathrm{NaOCl}$ or NaDCC in $300 \mathrm{NTU}$ sediments.

\section{Discussion}

We systematically assessed the impact of disinfectant, dosage, turbidity level, turbidity type, and added TOC concentration on residual maintenance and disinfection efficacy in the laboratory setting; testing a total of 324 reactors. We found that $\mathrm{NaOCl}$ and $\mathrm{NaDCC}$ had similar decay curves, while $\mathrm{ClO}_{2}$ was depleted more rapidly, which can be attributed to the volatile and gaseous nature of $\mathrm{ClO}_{2}$. Over 24 hours, $\mathrm{NaOCl}$ and $\mathrm{NaDCC}$ maintained adequate FCR $(\geq 0.2 \mathrm{mg} / \mathrm{L})$ up to high sediment-based turbidity (30-100 NTU) with both initial dosages of $2 \mathrm{mg} / \mathrm{L}$ and $4 \mathrm{mg} / \mathrm{L}$. In contrast, $\mathrm{ClO}_{2}$ residuals were $\geq 0.2 \mathrm{mg} / \mathrm{L}$ for only two of the nine conditions with an initial dosage of $2 \mathrm{mg} / \mathrm{L}$, and for eight out of nine conditions at a higher dosage $(4 \mathrm{mg} / \mathrm{L})$. In terms of efficacy, these results suggest that the three tested disinfectants would inactivate the three WHO Evaluation Scheme pathogens within one hour under all of the tested conditions, except the highest sediment turbidity (300 NTU) for $\mathrm{NaOCl}$ and $\mathrm{NaDCC}$. These results are generally concurrent with previous literature and informed practice, and suggest that $\mathrm{NaOCl}, \mathrm{NaDCC}$, and $\mathrm{ClO}_{2}$ are equally efficacious in terms of pathogen removal for HWT applications. However, $\mathrm{NaOCl}$ and $\mathrm{NaDCC}$ achieve higher residual maintenance, which is important to protect water from recontamination during storage in households. Our results inform the literature, particularly on the topics of: 1) The balance between disinfectant, dose, residual maintenance, and efficacy in HWT; and, 2) appropriate compounds to add in the laboratory setting to model natural waters.

While $\mathrm{NaOCl}$ and $\mathrm{NaDCC}$ retain similar FCR throughout the majority of reactors tested, there are slight differences at 24 hours for turbidity from sediments: 1) At 30 and 100 NTU, the first order decay constants are statistically different at both dosages, however at 300 NTU they are only different at $4 \mathrm{mg} / \mathrm{L} ; 2$ ) at $100 \mathrm{NTU}$, a difference is seen between the number of samples $\geq 0.2 \mathrm{mg} / \mathrm{L}$, but please 
note that this difference is not seen at 30 or 300 NTU. Taken together, these results indicate that the residual is slightly better maintained with NaDCC between 30-100 NTU. However, this only becomes practically and policy-relevant at $100 \mathrm{NTU}$, when fewer $\mathrm{NaOCl}$ results are $\geq 0.2 \mathrm{mg} / \mathrm{L}$ compared to NaDCC. By 300 NTU, the results converge again, as both chlorine compounds do not maintain FCR $\geq$ $0.2 \mathrm{mg} / \mathrm{L}$. These results are similar to results from 43 samples collected in Tanzania [31]. Thus, there is a question of how meaningful the slight statistical difference is in $\mathrm{NaOCl}$ and $\mathrm{NaDCC}$ between 30-100 NTU. Overall, these results support the current WHO and CDC recommendations to use 2 $\mathrm{mg} / \mathrm{L}$ of $\mathrm{NaDCC}$ or $\mathrm{NaOCl}$ for waters of turbidity $0-10 \mathrm{NTU}, 4 \mathrm{mg} / \mathrm{L}$ of $\mathrm{NaDCC}$ or $\mathrm{NaOCl}$ for waters of turbidity 10-100 NTU, and not to use chlorination alone at turbidities $>100$ NTU (as with these dosages a $\geq 0.2 \mathrm{mg} / \mathrm{L}$ is maintained over 24 hours) [16]. The decision whether to use $\mathrm{NaDCC}$ or $\mathrm{NaOCl}$ for water treatment will depend upon the context, including availability, cost, and user acceptance factors. Generally, NaDCC has the benefits of a longer shelf life (three years), but the drawbacks of a higher unit cost; while $\mathrm{NaOCl}$ has the benefits of a lower unit cost, but drawbacks of shorter shelf-life (12 months). Of note is that for high turbidity water, users should ideally be using a multi-barrier method for household water treatment, such as filtration or flocculation, followed by disinfection (e.g., chlorination) [6].

$\mathrm{ClO}_{2}$ has historically been used primarily for centralized water treatment due to its gaseous nature and instability, as it is made of free radicals and reacts quickly to treat water. $\mathrm{ClO}_{2}$ solutions have to be kept cool, sealed, and protected from light to avoid disproportionation [50], and this is difficult to ensure in field conditions relevant to HWT. Results from this study indicate that $\mathrm{ClO}_{2}$ decays more rapidly than $\mathrm{NaOCl}$ or $\mathrm{NaDCC}$, and may therefore not provide adequate protection from recontamination during water storage in households. However, new products have been released on the market, including $\mathrm{ClO}_{2}$ tablets [20], that offer promising perspectives for $\mathrm{HWT}$ applications and warrant further evaluations.

We tested three mechanisms to add chlorine demand to our test waters: Kaolin clay, added TOC standard, and creek-bed sediments. These mechanisms were selected to model the different types of chlorine demand producing compounds seen in field waters (clay from rivers, TOC from natural organic materials, and creek-bed sediments from river bottoms) [51]. However, as is evident in the study, two of these compounds appear to add little chlorine demand. As kaolin clay is purely mineral $\left(\mathrm{Al}_{2} \mathrm{H}_{4} \mathrm{O}_{9} \mathrm{Si}_{2}\right)$, it may not add chlorine demand to water.

There are different TOC standards available for laboratory settings, and we made an assumption that they would all have a chlorine demand. The TOC standard we used was produced from a dicarboxylic acid, monopotassium salt and phosphoric acid [34], which had limited chlorine demand.

We are not the first to make this assumption. The WHO and National Science Foundation (NSF) developed a testing protocol for evaluating HWT technologies against prepared test waters. The protocol calls for the use of tannic acid in general (low TOC) test waters and humic acid in challenge (high TOC) test waters [49]. The addition of tannic or humic acid is based on the weight of carbon in each compound. However, while this ensures that the additional organic carbon load is consistent, it does not account for any differences in chlorine demand exerted by varied TOC standards, including the different acids, as each acid is comprised of different organic materials (tannic acid is a polyphenol and humic acid has both phenolic and carboxylic substitutes). There were challenges in testing chlorine-based HWT products noted in the WHO Evaluation Scheme, and we are working in consultancy with WHO to determine ways to ensure that TOC additives to general and challenge test waters do not have controlled carbon addition, but instead that they have controlled chlorine demand addition, which is an accurate way to assess chlorine-based HWT products. Further research into accurate test waters with controlled chlorine demand to assess chlorine product efficacy is needed. We are currently working on this in our laboratory.

There are several limitations to this research. First, as noted above, the liquid TOC standard we used and the kaolin clay did not appear to add any chlorine (or chlorine dioxide) demand, which prevented our testing matrix from being as robust as originally hoped for. Second, we did not spike the 
samples with E. coli or other relevant microorganisms, which would have provided more information about disinfectant efficacy and the relationship between the mechanisms of chlorine demand addition and disinfectant efficacy. For example, clay could affect disinfection efficacy by making more particle surface areas available for bacteria to attach to [11]. Please note, in a recent laboratory study evaluating a $3.75 \mathrm{mg} / \mathrm{L} \mathrm{NaOCl}$ dosage, log reductions in E. coli were high (5.0-7.3 log after 1 hour) across kaolin clay-based turbidities ranging from 10 to 300 NTU [50]. Third, we intended to use chloramines as another alternative to $\mathrm{NaOCl}$ and $\mathrm{NaDCC}$, however preliminary laboratory testing suggested that chloramine $\mathrm{T}$ tablets would not release free chlorine even under the least challenging conditions (zero TOC and turbidity), possibly indicating that the tested product relies on bound chlorine (from chloramines) for disinfection. Fourth, we did not quantify TOC in our laboratory studies, which would have been particularly important for creek-bed sediments as they were collected on different days over the course of the study; additionally, increasing creek-bed sediment turbidity could have increased TOC. Lastly, we assumed that the CT-factors for $\mathrm{NaOCl}$ are appropriate for NaDCC.

Further research should be conducted to determine how each disinfectant responds to spikes of representative bacteria, viruses, and protozoa. Additionally, CT-factors for NaDCC should be determined in order to further compare the effectiveness of $\mathrm{NaDCC}$ and $\mathrm{NaOCl}$. Future work is needed on developing accurate and appropriate recommendations for test waters with controlled chlorine demand to challenge all available and newly-developed chlorine-based HWT products.

Supplementary Materials: The following are available online at http://www.mdpi.com/2073-4441/11/6/1309/s1, Table S1: Comparison of disinfectants: p-values from the post-hoc Tukey test. Table S2: Calculated CT factors for the three disinfectants under all tested conditions. Figure S1: Disinfectant residual concentration over time at varying turbidity from clay and varying added TOC for the $4 \mathrm{mg} / \mathrm{L}$ dosage.

Author Contributions: Conceptualization, D.L.; methodology, D.L., D.S., and K.G.; validation, D.L. and K.G.; formal analysis, K.G.; investigation, D.S. and K.G.; resources, D.L.; data curation, D.S. and K.G.; writing-original draft preparation, D.L., K.G., and D.S.; writing—review and editing, D.L., G.S., K.G., and D.S.; visualization, K.G.; supervision, D.L.; project administration, D.L.; funding acquisition, D.L.

Funding: This research received no external funding. It was supported by the Tufts Summer Scholars program and the Cataldo Fellowship (both internal research support programs at Tufts University).

Acknowledgments: We would like to thank Medentech and Xinix for donations of the NaDCC and chlorine dioxide products used in this study. We also would like to thank Amylee Anyoha for her help in the laboratory.

Conflicts of Interest: The authors declare no conflict of interest. The funders had no role in the design of the study; in the collection, analyses, or interpretation of data; in the writing of the manuscript, or in the decision to publish the results.

\section{References}

1. World Health Organization (WHO); United Nations Children's Fund (UNICEF). Progress on Drinking Water, Sanitation and Hygiene: 2017 Update and SDG Baselines; WHO: Geneva, Switzerland; UNICEF: New York, NY, USA, 2017.

2. Clasen, T.; Schmidt, W.P.; Rabie, T.; Roberts, I.; Cairncross, S. Interventions to improve water quality for preventing diarrhoea: systematic review and meta-analysis. BMJ 2007, 334, 782. [CrossRef] [PubMed]

3. Clasen, T. Household water treatment and safe storage to prevent diarrheal disease in developing countries. Curr. Environ. Health Rep. 2015, 2, 69-74. [CrossRef] [PubMed]

4. World Health Organization (WHO); United Nations Children's Fund (UNICEF). International Network on Household Water Treatment and Safe Stroage: Revised Strategy and Funding Proposal; WHO: Geneva, Switzerland; UNICEF: New York, NY, USA, 2011.

5. World Health Organization (WHO). Considerations for Policy Development and Scaling-Up Household Water Treatment and Safe Storage with Communicable Disease Prevention Efforts; WHO: Geneva, Switzerland, 2012.

6. Lantagne, D.; Quick, R.E.; Mintz, E. Household Water Treatment and Safe Storage Options in Developing Countries: A Review of Current Implementation Practices; Environmental Change and Security Program; Woodrow Wilson International Center for Scholars: Washington, DC, USA, 2006. 
7. Arnold, B.F.; Colford, J.M., Jr. Treating water with chlorine at point-of-use to improve water quality and reduce child diarrhea in developing countries: A systematic review and meta-analysis. Am. J. Trop. Med. Hyg. 2007, 76, 354-364. [CrossRef] [PubMed]

8. Medentech. Aquatabs®Water Disinfection Available Immediately. Available online: http://www.medentech. com/home/industries/water-purification/ (accessed on 4 January 2019).

9. PSI. Water Treatment. Available online: http://www.psi.org/health-area/water-sanitation/water-treatment/ \#about (accessed on 4 January 2019).

10. Lantagne, D.; Clasen, T. Use of household water treatment and safe storage methods in acute emergency response: Case study results from Nepal, Indonesia, Kenya, and Haiti. Environ. Sci. Technol. 2012, 46, 11352-11360. [CrossRef] [PubMed]

11. LeChevallier, M.W.; Evans, T.M.; Seidler, R.J. Effect of Turbidity on Chlorine Efficiency and Bacterial Persistence in Drinking water. Appl. Environ. Microbiol. 1981, 42, 159-167. [PubMed]

12. Black \& Veatch Corporation. White's Handbook of Chlorination and Alternative Disinfectants; John Wiley \& Sons: Hoboken, NJ, USA, 2010.

13. Deborde, M.; von Gunten, U. Reactions of chlorine with inorganic and organic compounds during water treatment-Kinetics and mechanisms: A critical review. J. Water Res. 2008, 42, 13-51. [CrossRef] [PubMed]

14. American Water Works Association (AWWA). Water Quality and Treatment: A Handbook for Community Water Supplies; McGraw-Hill: Denver, CO, USA, 1999.

15. American Public Health Association (APHA); American Water Works Association (AWWA); Water Environment Federation (WEF). Standard Methods for the Examination of Water and Wastewater, 23rd ed.; American Public Health Association: Washington, DC, USA, 2017; ISBN 9780875532875.

16. Lantagne, D. Sodium hypochlorite dosage for household and emergency water treatment. J. Am. Water Works Assoc. 2008, 100, 106-119. [CrossRef]

17. World Health Organization (WHO). Guidelines for Drinking-Water Quality, 4th ed.; WHO: Geneva, Switzerland, 2011.

18. Centers for Disease Control and Prevention (CDC). Safe Water System-Options for Pre-Treating Water in Chlorination Projects. Available online: https://www.cdc.gov/safewater/chlorination-pretreatment.html (accessed on 4 January 2019).

19. Xinix. Freebact Disinfectant. Available online: http://www.xinix.se/products/freebact/ (accessed on 4 January 2019).

20. Portable Aqua Chlorine Dioxide Water Purification Tablets. Available online: https://www.potableaqua.com/ products/pa-chlorine-dioxide-purification-tablets-2/ (accessed on 4 January 2019).

21. Scotmas. Safe, Reliable, and Cost-Effective $\mathrm{ClO} 2$ Solutions. Available online: https://www.scotmas.com/ products/chemicals.aspx (accessed on 4 January 2019).

22. Water Treatment Products, Ltd. Chlorine Dioxide Water Treatment. Available online: http: //www.watertreatmentproducts.co.uk/product-category/chlorine-dioxide-water-treatment/ (accessed on 4 January 2019).

23. Centers for Disease Control and Prevention (CDC). Safe Water for the Community: A Guide for Establishing A Community-Based Safe Water System Program; Centers for Disease Control and Prevention: Atlanta, GA, USA, 2008.

24. Lantagne, D.; Preston, K.; Blanton, E.; Kotlarz, N.; Gezagehn, H.; van Dusen, E.; Berens, J.; Jellison, K. Hypochlorite solution expiry and stability in household water treatment in developing countries. J. Environ. Eng. 2011, 137. [CrossRef]

25. Rook, J.J. Formation of haloforms during chlorination of natural waters. Water Treat. Exam. 1974, 23, $234-243$.

26. Lantagne, D.; Blount, B.C.; Cardinali, F.; Quick, R.E. Disinfection by-product formation and mitigation strategies in point-of-use chlorination of turbid and non-turbid waters in western Kenya. J. Water Health 2008, 6, 67-82. [CrossRef]

27. Clasen, T.; Edmonson, P. Sodium dichloroisocyanurate (NaDCC) tablets as an alternative to sodium hypochlorite for the routine treatment of drinking water at the household level. Int. J. Hyg. Environ. Health 2006, 209, 173-181. [CrossRef] [PubMed]

28. Kuszenof, P. Sodium Dichloroisocyanurate: Chemical and Technical Assessment; 61st JECFA; Food and Agriculture Organization (FAO) of the United Nations: Rome, Italy, 2004. 
29. Lantagne, D.; Cardinali, F.; Blount, B.C. Disinfection by-product formation and mitigation strategies in point-of-use chlorination with sodium dichloroisocyanurate in Tanzania. Am. J. Trop. Med. Hyg. 2010, 83, 135-143. [CrossRef] [PubMed]

30. Aieta, E.; Berg, J. A review of chlorine dioxide in drinking water treatment. J. Am. Water Works Assoc. 1986, 78, 62-72. [CrossRef]

31. Mohamed, H.; Brown, J.; Njee, R.M.; Clasen, T.; Malebo, H.M.; Mbuligwe, S. Point-of-use chlorination of turbid water: results from a field study in Tanzania. J. Water Health 2015, 13, 544-552. [CrossRef] [PubMed]

32. Kotlarz, N.; Lantagne, D.; Preston, K.; Jellison, K. Turbidity and chlorine demand reduction using locally available physical water clarification mechanisms before household chlorination in developing countries. J. Water Health 2009, 7, 497-506. [CrossRef]

33. Preston, K.; Lantagne, D.; Kotlarz, N.; Jellison, K. Turbidity and chlorine demand reduction using alum and moringa flocculation before household chlorination in developing countries. J. Water Health 2010, 8, 60-70. [CrossRef] [PubMed]

34. Safety Data Sheet_TOC Standard $10000 \mathrm{mg} / \mathrm{L}$ —Product Code \#5847000—SDS \#M02156. Available online: https://www.hach.com/toc-standard-solution-10000-mg-1-4-1/product-downloads?id=7640481435 (accessed on 25 June 2019).

35. Kaplan, L.A.; Newbold, J.D. Surface and Subsurface Dissolved Organic Carbon. In Streams and Ground Waters; Academic Press: Cambridge, MA, USA, 2000. [CrossRef]

36. American Public Health Association (APHA). 4500-Cl: Standard Methods for the Examination of Water and Wastewater; American Public Health Association: Washington, DC, USA, 1992.

37. American Public Health Association (APHA). 4500-ClO2: Standard Methods for the Examination of Water and Wastewater; American Public Health Association: Washington, DC, USA, 1992.

38. Murray, A.; Lantagne, D. Accuracy, precision, usability, and cost of free chlorine residual testing methods. J. Water Health 2015, 13, 79-90. [CrossRef]

39. Centers for Disease Control and Preventioen (CDC). Safe Water System (SWS)_Effect of Chlorination on Inactivating Selected Pathogens; Centers for Disease Control and Preventioen: Atlanta, GA, USA, 2008.

40. Kotloff, K.L.; Nataro, J.P.; Blackwelder, W.C.; Nasrin, D.; Farag, T.H.; Panchalingam, S.; Wu, Y.; Sow, S.O.; Sur, D.; Breiman, R.F.; et al. Burden and aetiology of diarrhoeal disease in infants and young children in developing countries (the Global Enteric Multicenter Study, GEMS): A prospective, case-control study. Lancet 2013, 382, 209-222. [CrossRef]

41. La Fauci, V.; Costa, G.B.; Arena, A.; Ventura Spagnolo, E.; Genovese, C.; Palamara, M.A.; Squeri, R. Trend of MDR-microorganisms isolated from the biological samples of patients with HAI and from the surfaces around that patient. New Microbiol. 2018, 41, 42-46.

42. D'Auria, F.D.; Simonetti, G.; Strippoli, V. Antimicrobial activity exerted by sodium dichloroisocyanurate. Annali di Igiene: Medicina Preventiva e di Comunita 1989, 1, 1445-1458.

43. Schlosser, O.; Robert, C.; Bourderioux, C.; Rey, M.; de Roubin, M.R. Bacterial removal from inexpensive portable water treatment systems for travelers. J. Travel Med. 2001, 8, 12-18. [CrossRef] [PubMed]

44. Gava Mazzola, P.; Vessoni Pena, T.C.; Martins, A.M. Determination of decimal reduction time (D value) of chemical agents used in hospitals for disinfection purposes. BMC Infect. Dis. 2003, 3, 24. [CrossRef] [PubMed]

45. LeChevallier, M.W.; Cawthon, D.C.; Lee, R.G. Inactivation of biofilm bacteria. Appl. Environ. Microbiol. 1988, 54, 2492-2499. [PubMed]

46. Xue, B.; Jin, M.; Yang, D.; Guo, X.; Chen, Z.; Shen, Z.; Wang, X.; Qiu, Z.; Wang, J.; Zhang, B.; et al. Effects of chlorine and chlorine dioxide on human rotavirus infectivity and genome stability. Water Res. 2013, 47, 3329-3338. [CrossRef] [PubMed]

47. Clark, R.M.; Black, D.A.; Pien, S.H.; Read, E.J. Predicting the Inactivation of Giardia Lamblia: A Mathematical and Statistical Model; Environmental Protection Agency: Washington, DC, USA, 1990.

48. US Environmental Protection Agency (US EPA). Guidance Manual for Compliance with the Filtration and Disinfection Requirements for Public Water Systems Using Surface Water Sources; Environmental Protection Agency: Washington, DC, USA, 1991.

49. World Health Organization (WHO). Harmonized Testing Protocol: Technology Non-Specific. WHO International Scheme to Evaluate Household Water Treatment Technologies; WHO: Geneva, Switzerland, 2014. 
50. Aieta, E.M.; Roberts, P.V.; Hernandez, M. Determination of Chlorine Dioxide, Chlorine, Chlorite, and Chlorate in Water. J. Am. Water Works Assoc. 1984, 76, 64-70. [CrossRef]

51. Wilhelm, N.; Kaufmann, A.; Blanton, E.; Lantagne, D. Sodium hypochlorite dosage for household and emergency water treatment: updated recommendations. J. Water Health 2018, 16, 112-126. [CrossRef]

(C) 2019 by the authors. Licensee MDPI, Basel, Switzerland. This article is an open access article distributed under the terms and conditions of the Creative Commons Attribution (CC BY) license (http://creativecommons.org/licenses/by/4.0/). 